Original article

\title{
Latent class analysis identified phenotypes in individuals with schizophrenia spectrum disorder who engage in aggressive behaviour towards others
}

\author{
S. Lau ${ }^{c, 1}$, M.P. Günther ${ }^{\mathrm{a}, 1, *}$, S. Kling ${ }^{\mathrm{b}}$, J. Kirchebner ${ }^{\mathrm{a}}$ \\ a Department of Psychiatry, Psychotherapy and Psychosomatics, University Hospital of Psychiatry Zurich, Zurich, Switzerland \\ ${ }^{\mathrm{b}}$ Computer Vision Laboratory, Department of Information Technology and Electrical Engineering, Swiss Federal Institute of Technology (ETH) Zurich, Zurich, \\ Switzerland \\ ${ }^{\mathrm{c}}$ Department of Forensic Psychiatry, University Hospital of Psychiatry Zurich, Zurich, Switzerland
}

\section{A R T I C L E I N F O}

\section{Article history:}

Received 12 March 2019

Received in revised form 18 May 2019

Accepted 18 May 2019

Available online 21 June 2019

\section{Keywords:}

Forensic psychiatry

Offenders with schizophrenia spectrum

disorder

Severe mental illness

Latent class analysis

\begin{abstract}
A B S T R A C T
Prior research on Hodgins' (2008) typology of offenders with schizophrenia spectrum disorders (SSD) has revealed inconsistencies in the number of subgroups and the operationalization of the concept. This study addressed these inconsistencies by applying latent class analysis (LCA) based on the most frequently explored variables in prior research. This novel case-centred methodology identified similarities and differences between the subjects contained in the sample instead of the variables explored. The LCA was performed on 71 variables taken from data on a previously unstudied sample of 370 case histories of offenders with SSD in a centre for inpatient forensic therapies in Switzerland. Results were compared with Hodgins' theoretically postulated patient typologies and confirm three separate homogeneous classes of schizophrenic delinquents. Previous inconsistencies and differences in operationalizations of the typology of offenders with SDD to be found in the literature are discussed.
\end{abstract}

(C) 2019 Elsevier Masson SAS. All rights reserved.

\section{Introduction}

Evidence demonstrates that-compared to the general population-both men and women with schizophrenia spectrum disorders (SSD) have an elevated risk of being convicted of nonviolent criminal offences, a higher risk of being convicted of violent criminal offences, and an even higher risk of being convicted of homicide [1,2]. Nonetheless, as a group, offenders suffering from SSD seem to be very heterogeneous. Efforts have been made to structure this heterogeneity [3], since this could lead to the identification of different patient pathways to criminal offending, and thereby open up new avenues for prevention and treatment.

One of these approaches is Hodgins' [4] theoretical framework. This is a typology investigating offender patients suffering from "severe mental illness" (SMI) [5,6]. Although this typology of three subgroups has been reviewed in a multitude of recent studies (see Table 1), results have been inconsistent. Earlier research has

\footnotetext{
* Corresponding author at: Psychiatrische Universitätsklinik Zürich, Heliosstrasse 32, 8032 Zürich, Switzerland.

E-mail address: moritz.guenther@med.uni-giessen.de (M.P. Günther).

${ }^{1} \mathrm{SL}$ and MG contributed equally to the work presented here, and should therefore be regarded as equivalent authors.
}

provided evidence on two of the three subgroups of offenders affected by SMI in general as well as SSD in particular [5-13]. It distinguished "early starters" (ES) from "late starters" (LS) operationalizing ES quite differently as either committing an offence before age $18[5,9,11]$, or being diagnosed with conduct disorder before age 15 [10,12], or as offending before first evidence for an SMI [7,8,14-16]. LS were operationalized as either committing an offence after age 18 [5,9,11], or not being diagnosed with conduct disorder before age $15[10,12]$, or offending after evidence of an SMI had been reported [7,8,14-16]. Whereas such differences in operationalization of the ES-LS typology complicate any synthesis and comparison of results [14,17], ES were generally found to have grown up more frequently in deprived families or separated from their biological parents, to have experienced physical abuse, to perform poorly in school, to have conduct problems, to use alcohol and illegal substances, and to commit a greater variety and number of crimes before being diagnosed with SMI (often in addition to a personality disorder).

More recent research on offenders with SSD [14-16] was also able to provide evidence for the third subgroup of offenders proposed by Hodgins [18] termed "late late starters" (LLS) or "first offenders" (FO). These are a small group of predominantly male offenders in their late $30 \mathrm{~s}$ with chronic schizophrenia, but without any prior history of aggressive or antisocial behaviour, who 
Table 1

Research on Hodgins' typology of offenders with severe mental illness.

\begin{tabular}{|c|c|c|c|c|c|}
\hline Study & Focus & Sample & Diagnoses & Method & Results \\
\hline (5) & ES, LS & $\begin{array}{l}272 \text { male offenders in Sweden, } \\
1988-1995\end{array}$ & Schizophrenia & t test & $\begin{array}{l}\text { Differences described in behaviour, } \\
\text { comorbid disorders, personality } \\
\text { traits, and referrals for treatment in } \\
\text { childhood, adolescence, and } \\
\text { adulthood }\end{array}$ \\
\hline (9) & ES, LS & $\begin{array}{l}102 \text { male and } 7 \text { female offenders } \\
\text { in Finland, } 1987-2000\end{array}$ & Schizophrenia & $\begin{array}{l}\text { Chi-square test, } \\
\text { Fisher two tailed } \\
\text { exact test, t test, } \\
\text { Mann-Whitney } \\
\text { test }\end{array}$ & $\begin{array}{l}\text { Differences found in offender but } \\
\text { not offence characteristics }\end{array}$ \\
\hline (6) & ES, LS & $\begin{array}{l}120 \text { men and } 85 \text { women aged an } \\
\text { average of } 38.5 \text { years on general } \\
\text { adult psychiatric wards in the } \\
\text { UK, 2004-2005 }\end{array}$ & $\begin{array}{l}\text { Schizophrenia, schizo-affective } \\
\text { disorder, bipolar disorder ( } 18.5 \%) \text {, } \\
\text { major depression }(4.4 \%) \text {, non-toxic } \\
\text { psychosis }(3.4 \%)\end{array}$ & $\begin{array}{l}\text { Chi-square test, } \\
\text { Mann-Whitney } \\
\text { test }\end{array}$ & $\begin{array}{l}\text { Differences described in offender } \\
\text { characteristics }\end{array}$ \\
\hline (10) & ES, LS & $\begin{array}{l}137 \text { men ( } 44 \text { offenders in prison, } \\
59 \text { offenders on forensic wards } \\
\text { and } 34 \text { non-offenders on general } \\
\text { adult psychiatric wards) in } \\
\text { Quebec, Canada, } 1998 \text { and later }\end{array}$ & $\begin{array}{l}\text { Bipolar disorder, major depression, } \\
\text { schizoaffective disorder, } \\
\text { schizophrenia, schizophreniform } \\
\text { disorder, delirious disorder, non- } \\
\text { specified psychotic disorder }\end{array}$ & $\begin{array}{l}\text { Chi-square test, } \\
\text { Fisher exact test }\end{array}$ & $\begin{array}{l}\text { Key differences described between } \\
\text { early and late starters on etiological } \\
\text { and symptom-related variables, as } \\
\text { well as in terms of antisocial } \\
\text { behaviour }\end{array}$ \\
\hline (13) & ES, LS & $\begin{array}{l}245 \text { male offenders in Canada, } \\
1998-2006\end{array}$ & $\begin{array}{l}\text { Schizophrenia, schizoaffective } \\
\text { disorder, delusional disorder, other } \\
\text { psychotic disorder including major } \\
\text { affective disorder with psychotic } \\
\text { features, organic brain syndrome } \\
\text { such as dementia, psychotic } \\
\text { disorder not otherwise specified, } \\
\text { bipolar affective disorder (types I } \\
\text { and II), and major depressive } \\
\text { disorder }\end{array}$ & $\begin{array}{l}\mathrm{t} \text { test, Fisher exact } \\
\text { test, Mann- } \\
\text { Whitney test }\end{array}$ & $\begin{array}{l}\text { Factors influencing violence } \\
\text { severity were explored. ES and LS } \\
\text { differed with respect to history of } \\
\text { violence, presence of a comorbid } \\
\text { clinical condition such as a } \\
\text { personality disorder or substance } \\
\text { abuse, and current life } \\
\text { circumstances }\end{array}$ \\
\hline (7) & ES, LS & $\begin{array}{l}1404 \text { male and } 190 \text { female high- } \\
\text { security hospital admissions in } \\
\text { England } 1972-2000\end{array}$ & Schizophrenia & $\begin{array}{l}\text { Multiple } \\
\text { imputation (MICE) } \\
\text { of missing values, } \\
\text { multivariate } \\
\text { logistic regression }\end{array}$ & $\begin{array}{l}\text { Factors associated with pre- } \\
\text { admission offending were paternal } \\
\text { criminal convictions, a larger } \\
\text { family size, and a younger age at } \\
\text { first use of illicit drugs and/or } \\
\text { smoking cigarettes, and maternal } \\
\text { separation }\end{array}$ \\
\hline (11) & ES, LS & $\begin{array}{l}142 \text { men, } 6 \text { women representing } \\
\text { a complete } 2 \text {-year discharge } \\
\text { cohort from one specialist secure } \\
\text { forensic hospital unit ( } 2001- \\
2002 \text { ) in Denmark }\end{array}$ & $\begin{array}{l}\text { Schizophrenia spectrum disorder, } \\
\text { covering ICD-10 categories F20-29 }\end{array}$ & $\begin{array}{l}\text { Chi-square test, } \\
\text { Fisher exact test, } \\
\text { Mann-Whitney } \\
\text { test, multiple } \\
\text { regression }\end{array}$ & $\begin{array}{l}\text { A subgroup of patients with early } \\
\text { onset anti-social behaviour was } \\
\text { confirmed }\end{array}$ \\
\hline (8) & ES, LS & $\begin{array}{l}331 \text { ( } 74.4 \% \text { male) offenders in } \\
\text { London and Manchester, UK, } \\
\text { 1994-1996 }\end{array}$ & $\begin{array}{l}88.3 \% \text { schizophrenia or } \\
\text { schizoaffective disorder, 6.0\% } \\
\text { affective psychosis, } 5.7 \% \text { "other" } \\
\text { psychosis }\end{array}$ & $\begin{array}{l}\text { Logistic regression } \\
\text { analysis }\end{array}$ & $\begin{array}{l}\text { Pre-morbid offenders more likely } \\
\text { to be male, have a lower IQ and } \\
\text { have had a history of neurological } \\
\text { abnormality; pre-morbid offenders } \\
\text { were found to commit more crimes } \\
\text { overall, but this was estimated to } \\
\text { be due to an excess of acquisitive, } \\
\text { drug, and minor offending rather } \\
\text { than violent offending }\end{array}$ \\
\hline$(12)$ & ES, LS & $\begin{array}{l}88 \text { male offenders in a forensic } \\
\text { hospital in Spain, 2012/2013 }\end{array}$ & $\begin{array}{l}\text { 67.0\% schizophrenia, } 15.9 \% \\
\text { delusional disorder, } 8.0 \% \\
\text { schizoaffective disorder, } 3.4 \% \\
\text { bipolar disorder, and } 5.7 \% \text { other } \\
\text { psychotic disorders }\end{array}$ & $\begin{array}{l}\text { Chi-square test, t } \\
\text { test, Mann- } \\
\text { Whitney test, six } \\
\text { forward stepwise } \\
\text { logistic regression } \\
\text { analyses }\end{array}$ & $\begin{array}{l}\text { Conduct disorder (CD) prior to age } \\
15 \text { was used to identify a subgroup } \\
\text { of men with severe mental illness } \\
\text { (SMI) who presented a high risk for } \\
\text { persistent violence across the } \\
\text { lifespan }\end{array}$ \\
\hline$(16)$ & $\begin{array}{l}97 \mathrm{ES}, 100 \mathrm{LS} \text {, and } 26 \text { first } \\
\text { offenders (FO) }\end{array}$ & $\begin{array}{l}223 \text { offenders ( } 94.2 \% \text { male, } 5.8 \% \\
\text { female) admitted in Utrecht, } \\
\text { Netherlands, 1993-2008 }\end{array}$ & $\begin{array}{l}\text { Schizophrenia spectrum disorder } \\
\text { (schizophrenia, schizoaffective } \\
\text { disorder, and delusional disorder; } \\
\text { DSM Axis 1) }\end{array}$ & $\begin{array}{l}\text { Chi-square test, } \\
\text { Fisher exact test }\end{array}$ & $\begin{array}{l}\text { Significant differences between the } \\
\text { explored subgroups were found } \\
\text { within the domains of life } \\
\text { functioning, abuse and family- } \\
\text { related problems, psychiatric } \\
\text { functioning, substance misuse, } \\
\text { antisocial personality, and offence } \\
\text { characteristics }\end{array}$ \\
\hline (15) & $\begin{array}{l}97 \mathrm{ES}, 100 \mathrm{LS} \text {, and } 26 \text { first } \\
\text { offenders (FO), } 129 \text { non- } \\
\text { offenders }\end{array}$ & $\begin{array}{l}223 \text { offenders ( } 94.2 \% \text { male, } 5.8 \% \\
\text { female) and } 129 \text { non-offenders } \\
\text { admitted in Utrecht and } \\
\text { Rotterdam, Netherlands, 1993- } \\
2008\end{array}$ & $\begin{array}{l}\text { Schizophrenia spectrum disorder } \\
\text { (schizophrenia, schizoaffective } \\
\text { disorder, and delusional disorder) }\end{array}$ & $\begin{array}{l}\text { Chi-square test, } \\
\text { Fisher exact test }\end{array}$ & $\begin{array}{l}\text { Little difference found between } \\
\text { early and later starters in terms of } \\
\text { measured antecedents, but } \\
\text { substance misuse was up to } 20 \\
\text { times less likely among late first } \\
\text { offenders. Persecutory and/or } \\
\text { grandiose delusions were more } \\
\text { strongly associated with each } \\
\text { offender group compared with } \\
\text { non-offenders and were strongest } \\
\text { in late first offenders }\end{array}$ \\
\hline
\end{tabular}


Table 1 (Continued)

\begin{tabular}{|c|c|c|c|c|c|}
\hline Study & Focus & Sample & Diagnoses & Method & Results \\
\hline (14) & $\begin{array}{l}\text { ES, LS, late late starters } \\
\text { (LLS) }\end{array}$ & $\begin{array}{l}232(86 \% \text { male }) \text { offenders in } \\
\text { forensic treatment in Ontario, } \\
\text { Canada }\end{array}$ & $\begin{array}{l}\text { Schizophrenia, schizoaffective } \\
\text { disorder, delusional disorder }\end{array}$ & Chi-square test & $\begin{array}{l}\text { Identified } 25 \% \text { early starters, } 67 \% \\
\text { late starters, and } 8 \% \text { late late } \\
\text { starters defined as late starters who } \\
\text { had experienced } 10+\text { years of } \\
\text { illness and were }>37 \text { years upon } \\
\text { first arrest; early starters more } \\
\text { often had a substance use disorder, } \\
\text { antisocial personality disorder, and } \\
\text { a greater number of static/ } \\
\text { historical risk factors for violence } \\
\text { and more previous criminal } \\
\text { contacts; mental illness was found } \\
\text { to start later in life for late late } \\
\text { starters who were was also more } \\
\text { likely to have been married and to } \\
\text { have a spouse as victim in the index } \\
\text { offence }\end{array}$ \\
\hline (19) & $\begin{array}{l}\text { Adolescent pre-illness } \\
\text { starters, adult pre-illness } \\
\text { starters, younger post- }\end{array}$ & $\begin{array}{l}1800 \text { ( } 84.4 \% \text { male }) \text { offenders in } \\
\text { Canada }\end{array}$ & $\begin{array}{l}\text { Psychotic spectrum disorders, } \\
\text { mood disorders }(-25 \%)\end{array}$ & $\begin{array}{l}\text { Logistic, negative } \\
\text { binomial, and Cox } \\
\text { regression analyses }\end{array}$ & $\begin{array}{l}\text { Five subgroups were identified } \\
\text { with the highest criminogenic } \\
\text { needs in pre-illness starters }\end{array}$ \\
\hline
\end{tabular}

illness starters, older post-

regression analyses needs in pre-illness starters

illness starters, first

presenters

(17) ES, LS

429 male and 78 female Schizophrenia (68\% rising to 88\% offenders in a forensic hospital in when including all psychoses), Ontario, Canada, 2010-2012 bipolar disorder (4\%), depression or anxiety (2\%), intellectual disability (10\%)
Latent profile analysis
Latent profile analysis supported a two-class solution in both men and women; earlier involvement in mental health and criminal justice systems correlated with higher levels of static risk factors and criminogenic needs

Note: LLS = late late starter, $\mathrm{FO}=$ first offender, $\mathrm{LS}=$ late starter, $\mathrm{ES}=$ early starter.

typically engage in (actual or attempted) homicide of those caring for them. Despite being described as suffering from SSD [18], LLS/ FO were also identified as a separate subgroup in a large sample of 1800 male and female offenders with SMI (including almost 25\% mood disorders in addition to schizophrenia spectrum disorders) in Canada [19]. Yet, in contrast, the application of a different statistical approach to a smaller sample of 429 male and 78 female offenders with SMI in the same country resulted in a model with only two subgroups providing the best model fit [17].

The present study is designed to resolve the above inconsistencies, including those concerning whether there are either two or three subgroups of offenders with SSD (Objective 1) and the different operationalizations of Hodgins' typology having been applied [18] (Objective 2). It aims to utilize a new methodology (Objective 3), and to explore different variables (Objective 4). It is to assess the number of subgroups in a previously unexplored sample of 370 offenders with SSD in Switzerland by means of an LCA of all the variables discussed most frequently in the literature (see Table 2).

\section{Methodology}

\subsection{Source of data}

A total of 370 offenders with schizophreniform disorders including all types of schizophrenia, schizoaffective disorder, and delusional disorder were identified among 1694 patients admitted to the Centre for Inpatient Forensic Therapies at the Zurich University Hospital of Psychiatry between 1982 and 2016. Their case files covering only one treatment period for each individual (the last, which was also always the longest admission) were included in the present study. They consisted of professionally documented anamneses, psychiatric inpatient and outpatient reports, police reports, testimonies, court proceedings, reports from social workers, and biannual reports from the nursing and care staff. Files were extensive and can be assumed to contain all relevant information on the health and biography of a patient due to the high medical and legal importance assigned to cases of forensic patients in Switzerland. Retrospective file analyses of these cases for the purposes of this study were approved by the Zurich Cantonal Ethics Committee.

\subsection{Preliminary data processing and measures}

A trained independent physician systematically reviewed all case files and conducted a directed qualitative content analysis [20]. A second trained independent rater encoded a random subsample of $10 \%$ of cases to assess inter-rater reliability. Cohen's Kappa [21] was 0.78 , which can be regarded as substantial [22]. The content analysis employed a questionnaire and rating protocol for coding based on the extended [23,24] set of criteria proposed by Seifert [25]. These criteria were augmented with those variables most frequently explored in current research on the topic (see Table 1 ). This ensured the inclusion of measures defined as being most similar to those explored in a large number of prior studies on Hodgins' typology $[4,18]$ (see Table 2 for definitions of operationalizations in this study and literature sources with similar operationalizations). Differences in operationalization were roughly as small as those between the available published studies on the subject (see Table 1 ). One example for this is the operationalization of difficulties in school (in contrast to not graduating from mandatory schooling). This was operationalized as repetition of a year in school. It seemed to be more objective than the self-reports of offenders [8] or reports from schools on the allocation of additional teaching resources [5] reported in prior research. Additionally, in contrast to previous research, this study differentiated more precisely between previous offences and index offences.

\subsection{Data analysis}

Data was assessed quantitatively using R Studio version 1.1.383. Before performing any statistical tests, multiple imputations 
Table 2

Variables explored in this and prior research on Hodgins' [18] typology of offenders with SMIs/SSDs.

\begin{tabular}{|c|c|c|}
\hline Variable in current study & Categorization in current study & Prior research with similar variable \\
\hline Age at index offence & $<21,21-35,>35$ & [19] [17] [14] \\
\hline Gender & Dichotomous (female, male) & {$[19][15,16][17][8][7][14][6]$} \\
\hline Marital status at time of index offence & Dichotomous (married, single) & {$[15][16],[8][12][10][14]$} \\
\hline Level of education & $\begin{array}{l}\text { Dichotomous (graduation from mandatory } \\
\text { schooling/no graduation from mandatory } \\
\text { schooling) }\end{array}$ & {$[15,16][8][12][7][11][14][9][6][5]$} \\
\hline Employment at time of index offence & $\begin{array}{l}\text { Unemployed/Em-ployed/Other (retired, } \\
\text { retraining, school) }\end{array}$ & {$[15,16][8][9][5]$} \\
\hline Conduct disorder as minor (age $<18$ years) & $\begin{array}{l}\text { Dichotomous (conduct disorder/no conduct } \\
\text { disorder) }\end{array}$ & [16] [12] [10] [9] [6] [5] \\
\hline Disciplinary sanctions as minor (age $<18$ years) & Dichotomous (yes/no) & {$[16][7][11][6][5]$} \\
\hline Mental health treatment as minor (age $<18$ years) & Dichotomous (yes/no) & [9] [14] [5] \\
\hline Victim of physical abuse as minor (age $<18$ years) & Dichotomous (yes/no) & {$[15,16][12][10]$} \\
\hline Victim of sexual abuse as minor (age $<18$ years) & Dichotomous (yes/no) & {$[15,16][10]$} \\
\hline Separation from family as minor (age $<18$ years) & Dichotomous (yes/no) & {$[15,16][7][5]$} \\
\hline Mental illness of parents & Dichotomous (yes/no) & {$[15,16][12][7][10][9][6][5]$} \\
\hline Parental substance use & Dichotomous (yes/no) & {$[15,16][10][9]$} \\
\hline Parental delinquency & Dichotomous (yes/no) & {$[15,16][12][10][6]$} \\
\hline Victim of emotional neglect as minor (age $<18$ years) & Dichotomous (yes/no) & {$[15,16]$} \\
\hline Substance use as minor (age $<18$ years) & Dichotomous (yes/no) & {$[15,16][14][8][7][5]$} \\
\hline Repeating a year at school as minor (age $<18$ years) & Dichotomous (yes/no) & [8] [5] \\
\hline Age at first diagnosis of schizophrenia & $<21,21-35,>35$ & {$[15,16][14][5]$} \\
\hline Age at illness onset & $<21,21-35,>35$ & {$[15,16][17][14][5]$} \\
\hline Alcohol use & No use/Misuse/Abuse & {$[15,16][14][17][8][13][9][6][5]$} \\
\hline Illegal substance use & Dichotomous (yes/no) & {$[15,16][14][17][8][12][13][9][6][5]$} \\
\hline Cannabis use & Dichotomous (yes/no) & {$[15,16][5]$} \\
\hline Personality disorder diagnosed prior to admission & Dichotomous (yes/no) & [16] [17] [12] [7] [13] [14] [9] [5] \\
\hline Age at first inpatient treatment & $<21,21-35,>35$ & [17] [14] [5] \\
\hline Number of inpatient treatments & $\leq 1,2-5,>5$ & [19] [7] [9] [6] [5] \\
\hline Homelessness at time of index offence & Dichotomous (yes/no) & [19] [12] [8] [6] \\
\hline Number of criminal registry entries & $0,1,2-3,4-8,>8$ & [19] [14] [17] [11] [13] [10] [5] \\
\hline Age at first criminal registry entry & $<21,21-35,>35$ & {$[15,16][17][8,14][12][5]$} \\
\hline Previous offences: homicide, attempted homicide & Dichotomous (yes/no) & [16] [8] [9] \\
\hline Previous offences: assault & Dichotomous (yes/no) & [16] [8] [9] [6] \\
\hline Previous offences: threat, coercion & Dichotomous (yes/no) & [8] \\
\hline Previous offences: sexual abuse of children & Dichotomous (yes/no) & \\
\hline Previous offences: rape, sexual assault & Dichotomous (yes/no) & [8] \\
\hline Previous offences: other sexual offence & Dichotomous (yes/no) & [8] \\
\hline Previous offences: property crime without violence & Dichotomous (yes/no) & [8] \\
\hline Previous offences: property crime with violence & Dichotomous (yes/no) & [8] \\
\hline Previous offences: arson & Dichotomous (yes/no) & [8] [9] \\
\hline Previous offences: criminal damage & Dichotomous (yes/no) & [8] [9] \\
\hline Previous offences: traffic offences & Dichotomous (yes/no) & [8] [9] \\
\hline Previous offences: controlled substances act & Dichotomous (yes/no) & [16] [8] [9] \\
\hline Previous offences: offences against the weapons act & Dichotomous (yes/no) & [8] \\
\hline Previous offences: other offences & Dichotomous (yes/no) & [8] [9] \\
\hline Number of previous convictions & $0,1,2-3,4-8,>8$ & {$[15,16][14][9][13]$} \\
\hline Index offence: homicide, attempted homicide & Dichotomous (yes/no) & [12] \\
\hline Index offence: assault & Dichotomous (yes/no) & [12] \\
\hline Index offence: threat, coercion & Dichotomous (yes/no) & {$[12]$} \\
\hline Index offence: sexual abuse of children & Dichotomous (yes/no) & \\
\hline Index offence: rape, sexual assault & Dichotomous (yes/no) & [12] \\
\hline Index offence: other sexual offence & Dichotomous (yes/no) & [12] \\
\hline Index offence: property crime without violence & Dichotomous (yes/no) & [12] \\
\hline Index offence: property crime with violence & Dichotomous (yes/no) & [12] \\
\hline Index offence: arson & Dichotomous (yes/no) & \\
\hline Index offence: criminal damage & Dichotomous (yes/no) & [12] \\
\hline Index offence: traffic offences & Dichotomous (yes/no) & \\
\hline Index offence: controlled substances act & Dichotomous (yes/no) & \\
\hline Index offence: offences against the weapons act & Dichotomous (yes/no) & \\
\hline Index offence: misuse of emergency system & Dichotomous (yes/no) & \\
\hline Index offence: other offences & Dichotomous (yes/no) & [9] \\
\hline Duration of forensic treatment to date (in weeks) & $\begin{array}{l}3 \text { groups with approximately equal numbers of } \\
\text { observations }\end{array}$ & [19] [7] [6] [5] \\
\hline Crime-schizophrenia-sequence variable & $\begin{array}{l}\text { (Years since first crime-years since first } \\
\text { symptoms of schizophrenia) } \\
\text { if positive = ES; if } 0 \text { \& age }>35=\mathrm{LLS} / \mathrm{FO} \text {; rest = LS }\end{array}$ & {$[15,16][7][8][13][11][5][19][14]$} \\
\hline Severity of index offence & $\begin{array}{l}1 \text { = homicide, attempted homicide, } 2 \text { = sexual } \\
\text { abuse of children, rape, sexual assault, } 3=\text { other } \\
\text { sexual offence, } 4=\text { assault, } 5=\text { property crime, } 6 \\
\text { = threat, coercion, arson, criminal damage, } \\
\text { traffic offence, offence against controlled } \\
\text { substances act, offence against weapons act, } \\
\text { misuse of emergency system, other offences }\end{array}$ & [19] [8] [11] [9] [6] [13] \\
\hline
\end{tabular}


$[26,27]$ by chained equations (MICE) [28] were executed to address missing values. MICE maintains the variability of missing data, and integrates the uncertainty caused by estimating them. It is considered to be one of the best methods for imputing missing values [29]. The entire data set of 71 items was used to impute missing values with a total of 20 iterations of imputation.

Next, latent class analysis (LCA) was performed. LCA is a type of finite mixture model designed for analysing multivariate categorical data. It groups each observation probabilistically into an unobserved (= latent) nominal class, while minimizing the confusion between different observed items. LCA was conducted with the poLCA package implemented in R, which estimates the latent class model by maximizing the log-likelihood function using the expectation maximization (EM) algorithm.

Different numbers of classes ( 1 to 4 ) were evaluated to identify the most parsimonious model with the overall best fit representing the entire data set of 71 items and 370 observations (see Table 3 ). For a given number of classes, each latent class analysis was repeated 500 times with different starting values to avoid local extrema. In Class analyses 1 and 4, each item was assigned the same prior probability of belonging to a set class, given that no particular expectation regarding classification was available from the literature. In contrast, in Class analyses 2 and 3, the individual priors were allowed to vary depending on a covariate defined as the crime-schizophrenia-sequence variable. This variable classified patients into ES and LS (two-class model), or into ES, LS, and FO/LLS (three-class model) according to Hodgins' [4] and related research [14-16,19] on her framework: ES had entries in the criminal registry prior to first symptoms of a SSD; LS had symptoms of a SSD prior to an entry in the criminal registry that had to be recorded for a crime committed before age 35; and LLS had symptoms of a SSD prior to an entry in the criminal registry that had to be recorded for a crime committed after age 35 .

A set of different measures was computed to assess model fit and to compare results with the previous literature. These were the maximum log-likelihood, the Bayesian information criterion (BIC),
Akaike's information criterion (AIC), and entropy. Whereas maximum log-likelihood is exclusively a measure of goodness of model fit, BIC and AIC are measures of parsimony aiming to avoid over-fitting. Entropy is a measure of classification uncertainty [30], with values of $>0.8$ indicating a good separation between classes. For a particular number of classes, the model with the lowest loglikelihood was selected. To subsequently compare models between different numbers of classes, information criteria were evaluated. BIC penalizes additional model parameters more strongly than AIC and hence can be considered more conservative in preventing over-fitting. As a consequence, AIC has been reported to overestimate the correct number of components in a finite mixture model [31], whereas BIC performs more adequately [32]. For this reason, BIC was prioritized over AIC in selecting the best model fit. scBIC is a sample-size-corrected BIC value being computed for completeness. To further evaluate model fit with respect to the predicted classification in two- and three-class models, a chi-square test was performed to test for an association between the predicted typologies and the identified classes.

\section{Results}

The lowest BIC and scBIC values - indicating best model fit in terms of model complexity and parsimony - were observed in the two-class and three-class models (see Table 3).

Given that BIC criteria were close and ambiguous for both model fits, the relevance of the identified classes was further evaluated in order to decide which model better represented the data in terms of identifying patient subcategories. Fig. 1 shows the normalized probability of class membership (i.e. the posterior probability of class membership divided by the probability of random assignment to a class) for the different patient subcategories. Here, the two-class model showed the same trend in both patient categories: a lower probability of belonging to Class 1 compared to Class 2 . In contrast, the three-class model had more similar maximum probabilities of class membership, whereas inter-categorical differences were larger.

Table 3

LCA model fit evaluation criteria.

\begin{tabular}{|c|c|c|c|c|c|c|c|c|}
\hline $\begin{array}{l}\text { Number of } \\
\text { classes }\end{array}$ & $\begin{array}{l}\text { Number of estimated } \\
\text { parameters }\end{array}$ & $\begin{array}{l}\text { Residual degrees } \\
\text { of freedom }\end{array}$ & $\begin{array}{l}\text { Maximum } \\
\text { log-likelihood }\end{array}$ & AIC & BIC & scBIC & Entropy & Number of times solution was found \\
\hline 1 & 81 & 289 & -12769 & 25696 & 26006 & 26239 & - & $500 / 500$ \\
\hline 2 & 163 & 207 & -12164 & 24648 & 25275 & 25739 & 0.881 & $448 / 500$ \\
\hline 3 & 245 & 125 & -11890 & 24261 & 25204 & 25899 & 0.966 & $32 / 500$ \\
\hline 4 & 327 & 43 & -11674 & 23987 & 25235 & 26179 & 0.972 & $5 / 500$ \\
\hline
\end{tabular}

Note: AIC = Akaike's information criterion; BIC = Bayesian information criterion; entropy = measure of classification uncertainty.

A

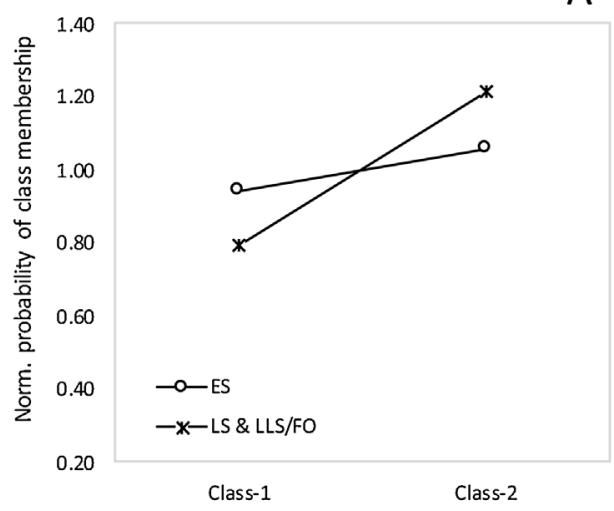

A

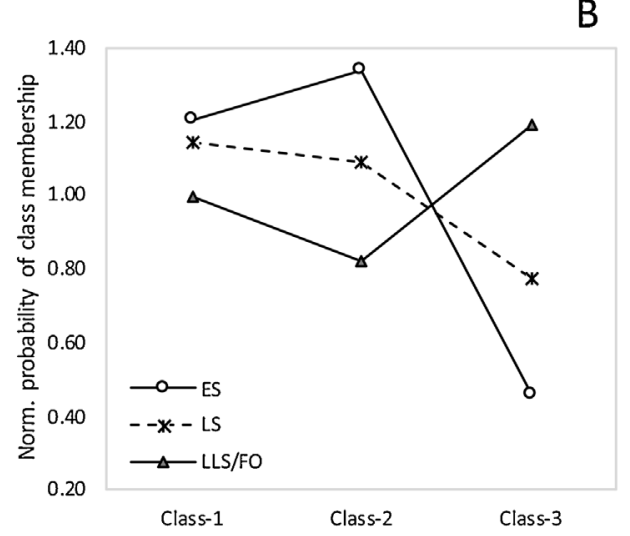

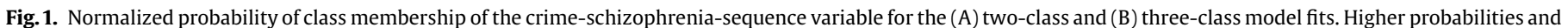

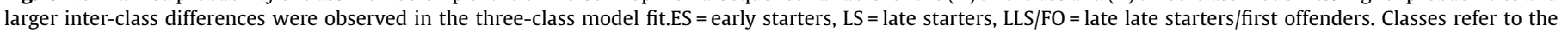
model-identified classes. Normalized probability refers to the posterior probability resulting from the LCA divided by the probability of random class membership. 
Table 4

Contingency tables for the two-class and three-class models.

\begin{tabular}{|c|c|c|c|c|}
\hline \multicolumn{5}{|c|}{ Two-class model: } \\
\hline & Class 1 & Class 2 & & \\
\hline ES & 112 & 52 & 164 & \\
\hline LS \& LLS/FO & 127 & 79 & 206 & \\
\hline & 239 & 131 & 370 & \\
\hline \multicolumn{5}{|c|}{ Three-class model: } \\
\hline & Class 1 & Class 2 & \multicolumn{2}{|l|}{ Class 3} \\
\hline ES & 87 & 49 & 7 & 143 \\
\hline LS & 104 & 34 & 12 & 150 \\
\hline \multirow{2}{*}{ LLS/FO } & 47 & 0 & 30 & 77 \\
\hline & 238 & 83 & 49 & 370 \\
\hline
\end{tabular}

Note: There was a significant association between the three-class model fit and Hodgins' typology $(\mathrm{p}=0.005)$, but not between the two-class model fit and the early-starters and late-starters typology $(\mathrm{p}=0.191)$.

$\mathrm{ES}=$ early starters; $\mathrm{LS}=$ late starters; LLS/FO = late late starters/first offenders.

In addition, a chi-square test performed on the contingency tables presented in Table 4 evaluating the matching between predicted categories and model-identified classes, was only significant for the three-class model $(p=0.005)$, but not for the two-class model $(p=0.191)$. This indicates a significant association between the three-class model and Hodgins' predicted subcategories. Hence, the three-class model could better capture previously described patient subcategories. Therefore, subsequent data interpretation was performed on this model. Table 5 presents the posterior probability of each item belonging to a specific class in the selected three-class model. Posterior probabilities, conditional on the observed manifest variable, were computed using Bayes formula as described earlier [33].

For subsequent class-specific interpretation, only variables showing at least a $10 \%$ or larger difference in class membership probabilities among categories were considered(see Table 5).

\subsection{Class 1}

In comparison to the other two classes, patients in this subgroup seem to have the best clinical match to Hodgins' [4] description of the early starters (ES) and are estimated to include $39 \%$ of the total study population. They most probably face multiple challenges as minors, including disciplinary sanctions, being diagnosed with a conduct disorder, receiving mental health treatment, being the victim of physical abuse and emotional neglect, growing up separated from their biological parents, using legal and illegal substances, repeating a year in school, and not graduating from mandatory schooling. Their parents most probably also use illegal substances and alcohol. Patients in this subgroup are most probably less than 21 years old when first prodromal symptoms of an SSD are documented, an SSD is diagnosed, a first psychiatric inpatient treatment is given, a first criminal registry entry is recorded, and the index offence is committed. They most probably abuse alcohol and cannabis (but not illegal substances in general-for which they have the lowest probability). They have the highest probability of receiving more than five inpatient treatments and more than four criminal registry entries by the time they enter forensic inpatient treatment. Offences most probably include property crime, offences against the weapons act, and petty offences such as transgressions of traffic law or the controlled substances act. They are most probably single, unemployed, and homeless.

\subsection{Class 2}

Estimated characteristics of patients in this subgroup (estimated to compose $40 \%$ of the study population) seem to best resemble those described for late starters (LS). Compared to other subgroups, patients reveal the lowest probability of having experienced physical abuse as minors and the highest probability of refraining from the use of alcohol. Age of estimated illness onset, first diagnosis of an SSD, first psychiatric inpatient treatment, as well as first criminal registry entry is most probably between 21 and 35 . Probabilities for all other variables differ less than $10 \%$ from those estimated for the other subgroups. Crimes committed seem to be similar to those committed by those in Class 1, but include fewer petty offences, fewer property crimes (especially such without violence), and fewer threats and coercion.

\subsection{Class 3}

Patient characteristics in Class 3 (21\% of the sample) seem to best fit previous descriptions of offenders referred to as late late starters (LLS) or first offenders (FO). They have least probably been diagnosed with a conduct disorder as a minor. Although they most probably use illegal substances, these least probably include cannabis. Age of estimated illness onset, first diagnosis of an SSD, first psychiatric inpatient treatment, first criminal registry entry, and index offence are most probably after the age of 35. Previous offences are most likely to include sexual offences, and the index offence is most likely to involve threat or coercion. They are much more probably married and slightly more probably female.

As a final note pertaining to all three subgroups, the two most probable index offences are attempted or executed homicide and assault, confirming prior research noting there may be more differences in offender than offence characteristics [9].

Fig. 2 presents the distribution of classes in a set of selected items. Interestingly, individual age-related variables separated the classes surprisingly well.

\section{Discussion}

This study applied LCA as a case-centred analytic approach and focused on similarities and differences between classes of offenders with SSD instead of between the variables examined. Based on a set of variables similar to the one most frequently used in extant research (see Table 2), it analysed a previously unexplored sample of offenders with SSD. The study confirms the existence of the three subgroups of offenders proposed in prior research [14-16,19]. Therefore, as proposed in the introduction, the results of this study are able to reduce doubts raised by inconsistencies in prior research about the existence of three distinct subgroups (Objective 1 ), to combine different operationalizations of Hodgins' $[4,18]$ typology (Objective 2 ) and variables (Objective 4), while using a more applicable [17] novel statistical methodology (Objective 3).

Results (in Table 5) indicate each of the variables operationalizing Hodgins' offender typology (18)-in terms of age at first inpatient treatment (Fig. 2, D), age at estimated illness onset (Fig. 2, C), or age at first diagnosis of a SSD (Fig. 2, B)-differentiate better between subgroups of offender patients than the crime-schizophrenia-sequence variable (Fig. 2, E) used as a covariate in this study and as a grouping variable in other most recent research on this issue [14-16,19]. The overall rather poor ability of the latter to distinguish subgroups is also reflected in the contingency table (Table 4) for the three-class model.

Nonetheless, there are two major shortcomings when the sole parameter for subgrouping is age at either first symptoms, first inpatient treatment, or diagnosis. First, offending may delay treatment of SSD $[7,16]$ and thus result in false subgroupings of offender patients. Second, whether women are analysed separately (sample size permitting), as proposed in recent research on psychoses in women [34], or together with male patients may also 
Table 5

Posterior probability of each item category belonging to a specific class.

\begin{tabular}{|c|c|c|c|c|}
\hline Item & Class 1 & Class 2 & Class 3 & $\begin{array}{l}\text { Max. difference } \\
\text { within category }\end{array}$ \\
\hline \multicolumn{5}{|l|}{ Gender } \\
\hline - Male & 0.9275 & 0.9424 & 0.8445 & $10 \%$ \\
\hline \multirow{2}{*}{\multicolumn{5}{|c|}{ Marital status at time of index offence }} \\
\hline & & & & \\
\hline - Married & 0.0644 & 0.1857 & 0.4146 & $35 \%$ \\
\hline - Single & 0.9356 & 0.8143 & 0.5854 & $35 \%$ \\
\hline \multicolumn{5}{|l|}{ Highest level of education } \\
\hline - No graduation from mandatory schooling & 0.3325 & 0.2299 & 0.2330 & $10 \%$ \\
\hline - Graduated mandatory schooling & 0.6675 & 0.7701 & 0.7670 & $10 \%$ \\
\hline \multicolumn{5}{|l|}{ Employment at time of index offence } \\
\hline • Unemployed & 0.8614 & 0.6514 & 0.6761 & $21 \%$ \\
\hline - Employed & 0.1091 & 0.2766 & 0.2721 & $17 \%$ \\
\hline - Other (retraining, school, retired) & 0.0295 & 0.072 & 0.0518 & $4 \%$ \\
\hline \multicolumn{5}{|l|}{ Homelessness at time of index offence } \\
\hline - No & 0.6365 & 0.8548 & 0.7511 & $22 \%$ \\
\hline - Yes & 0.3635 & 0.1452 & 0.2489 & $22 \%$ \\
\hline \multicolumn{5}{|l|}{ Conduct disorder as minor $($ age $<18)$} \\
\hline - No & 0.4724 & 0.7976 & 0.9072 & $43 \%$ \\
\hline - Yes & 0.5276 & 0.2024 & 0.0928 & $43 \%$ \\
\hline \multicolumn{5}{|l|}{ Disciplinary sanctions as minor (age $<18$ ) } \\
\hline - No & 0.2392 & 0.6663 & 0.7781 & $54 \%$ \\
\hline - Yes & 0.7608 & 0.3337 & 0.2219 & $54 \%$ \\
\hline \multicolumn{5}{|l|}{ Mental health treatment as minor (age $<18$ ) } \\
\hline - No & 0.5122 & 0.9063 & 0.9594 & $45 \%$ \\
\hline - Yes & 0.4878 & 0.0937 & 0.0406 & $45 \%$ \\
\hline \multicolumn{5}{|l|}{ Victim of physical abuse as minor (age $<18$ ) } \\
\hline - No & 0.5153 & 0.7492 & 0.6235 & $23 \%$ \\
\hline - Yes & 0.4847 & 0.2508 & 0.3765 & $23 \%$ \\
\hline \multicolumn{5}{|l|}{ Victim of sexual abuse as minor (age $<18$ ) } \\
\hline - No & 0.9501 & 0.9809 & 0.9611 & $3 \%$ \\
\hline - Yes & 0.0499 & 0.0191 & 0.0389 & $3 \%$ \\
\hline Victim of emotional neglect as minor (age $<$ & & & & \\
\hline - No & 0.5328 & 0.7857 & 0.6887 & $25 \%$ \\
\hline - Yes & 0.4672 & 0.2143 & 0.3113 & $25 \%$ \\
\hline Separation from family as minor (age $<18$ ) & & & & \\
\hline - No & 0.5004 & 0.7033 & 0.7013 & $20 \%$ \\
\hline - Yes & 0.4996 & 0.2967 & 0.2987 & $20 \%$ \\
\hline Mental illness of parents & & & & \\
\hline - No & 0.6809 & 0.7634 & 0.7681 & $9 \%$ \\
\hline - Yes & 0.3191 & 0.2366 & 0.2319 & $9 \%$ \\
\hline Parental substance use & & & & \\
\hline - No & 0.5668 & 0.7331 & 0.6757 & $17 \%$ \\
\hline - Yes & 0.4332 & 0.2669 & 0.3243 & $17 \%$ \\
\hline Parental delinquency & & & & \\
\hline - No & 0.8667 & 0.9007 & 0.9474 & $8 \%$ \\
\hline - Yes & 0.1333 & 0.0993 & 0.0526 & $8 \%$ \\
\hline Substance use as minor (age < 18) & & & & \\
\hline - No & 0.2373 & 0.8420 & 0.9204 & $68 \%$ \\
\hline - Yes & 0.7627 & 0.1580 & 0.0796 & $68 \%$ \\
\hline Repeating a year at school as minor (age $<18$ & & & & \\
\hline - No & 0.2818 & 0.6257 & 0.5835 & $34 \%$ \\
\hline - Yes & 0.7182 & 0.3743 & 0.4165 & $34 \%$ \\
\hline Alcohol use & & & & \\
\hline - No use & 0.2376 & 0.4946 & 0.4013 & $26 \%$ \\
\hline - Abuse & 0.4604 & 0.3805 & 0.3905 & $8 \%$ \\
\hline - Misuse & 0.3020 & 0.1249 & 0.2082 & $18 \%$ \\
\hline Illegal substance use & & & & \\
\hline - No & 0.9605 & 0.6367 & 0.4690 & $49 \%$ \\
\hline - Yes & 0.0395 & 0.3633 & 0.5310 & $49 \%$ \\
\hline Cannabis use & & & & \\
\hline - No & 0.1681 & 0.4934 & 0.6363 & $47 \%$ \\
\hline - Yes & 0.8319 & 0.5066 & 0.3637 & $47 \%$ \\
\hline Personality disorder diagnosed prior to admis & & & & \\
\hline - No & 0.1895 & 0.0721 & 0.1175 & $12 \%$ \\
\hline - Yes & 0.8105 & 0.9279 & 0.8825 & $12 \%$ \\
\hline Number of inpatient treatments & & & & \\
\hline - $\leq 1$ & 0.2054 & 0.2704 & 0.1960 & $7 \%$ \\
\hline - $2-5$ & 0.2871 & 0.3809 & 0.5428 & $26 \%$ \\
\hline - > 5 & 0.5075 & 0.3486 & 0.2611 & $25 \%$ \\
\hline Age at estimated illness onset (first documente & & & & \\
\hline$\bullet<21$ & 0.7186 & 0.3081 & 0.0517 & $67 \%$ \\
\hline - 21-35 & 0.2814 & 0.6852 & 0.3265 & $40 \%$ \\
\hline
\end{tabular}


Table 5 (Continued)

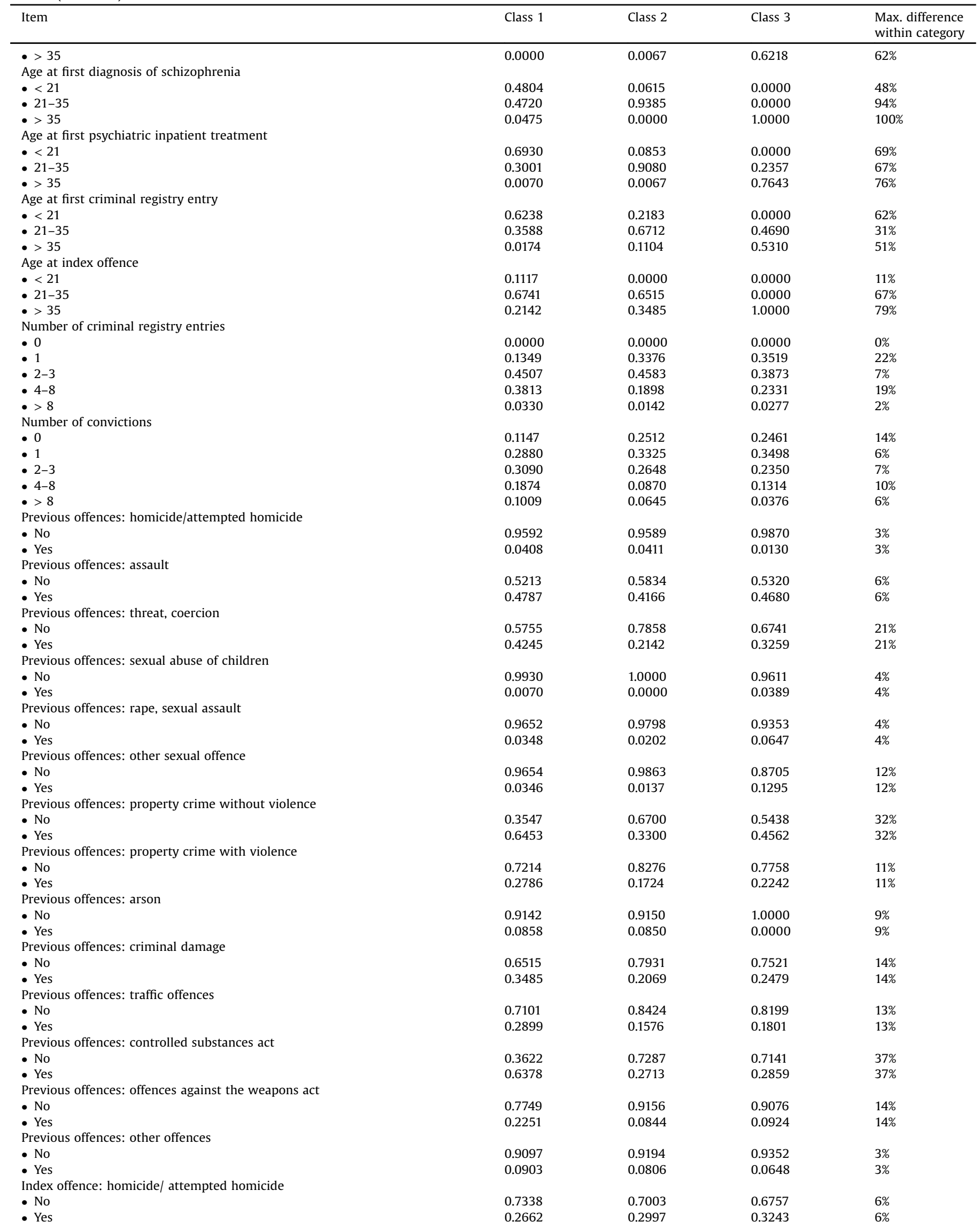


Table 5 (Continued)

\begin{tabular}{|c|c|c|c|c|}
\hline Item & Class 1 & Class 2 & Class 3 & $\begin{array}{l}\text { Max. difference } \\
\text { within category }\end{array}$ \\
\hline \multicolumn{5}{|l|}{ Index offence: assault } \\
\hline - No & 0.6040 & 0.6037 & 0.5725 & $3 \%$ \\
\hline - Yes & 0.3960 & 0.3963 & 0.4275 & $3 \%$ \\
\hline \multicolumn{5}{|l|}{ Index offence: threat, coercion } \\
\hline - No & 0.7525 & 0.7422 & 0.5597 & $19 \%$ \\
\hline - Yes & 0.2475 & 0.2578 & 0.4403 & $19 \%$ \\
\hline \multicolumn{5}{|l|}{ Index offence: sexual abuse of children } \\
\hline - No & 1.0000 & 0.9666 & 0.9482 & $5 \%$ \\
\hline - Yes & 0.0000 & 0.0334 & 0.0518 & $5 \%$ \\
\hline \multicolumn{5}{|l|}{ Index offence: rape, sexual assault } \\
\hline - No & 0.9085 & 0.9265 & 0.9236 & $2 \%$ \\
\hline - Yes & 0.0915 & 0.0735 & 0.0764 & $2 \%$ \\
\hline \multicolumn{5}{|l|}{ Index offence: other sexual offence } \\
\hline - No & 0.9519 & 0.9056 & 0.9482 & $5 \%$ \\
\hline - Yes & 0.0481 & 0.0944 & 0.0518 & $5 \%$ \\
\hline \multicolumn{5}{|l|}{ Index offence: property crime without violence } \\
\hline - No & 0.7811 & 0.8419 & 0.8575 & $8 \%$ \\
\hline - Yes & 0.2189 & 0.1581 & 0.1425 & $8 \%$ \\
\hline \multicolumn{5}{|l|}{ Index offence: property crime with violence } \\
\hline - No & 0.8773 & 0.9704 & 0.9870 & $11 \%$ \\
\hline - Yes & 0.1227 & 0.0296 & 0.0130 & $11 \%$ \\
\hline \multicolumn{5}{|l|}{ Index offence: arson } \\
\hline - No & 0.8615 & 0.9053 & 0.9611 & $10 \%$ \\
\hline - Yes & 0.1385 & 0.0947 & 0.0389 & $10 \%$ \\
\hline \multicolumn{5}{|l|}{ Index offence: criminal damage } \\
\hline - No & 0.8176 & 0.8671 & 0.9093 & $9 \%$ \\
\hline - Yes & 0.1824 & 0.1329 & 0.0907 & $9 \%$ \\
\hline \multicolumn{5}{|l|}{ Index offence: traffic offences } \\
\hline - No & 0.9563 & 0.9215 & 0.9611 & $4 \%$ \\
\hline - Yes & 0.0437 & 0.0785 & 0.0389 & $4 \%$ \\
\hline \multicolumn{5}{|l|}{ Index offence: controlled substances act } \\
\hline - No & 0.7451 & 0.8775 & 0.933 & $19 \%$ \\
\hline - Yes & 0.2549 & 0.1225 & 0.067 & $19 \%$ \\
\hline \multicolumn{5}{|l|}{ Index offence: offences against the weapons act } \\
\hline - No & 0.9242 & 0.9790 & 0.9222 & $6 \%$ \\
\hline - Yes & 0.0758 & 0.0210 & 0.0778 & $6 \%$ \\
\hline \multicolumn{5}{|l|}{ Index offence: misuse of emergency system } \\
\hline - No & 0.9789 & 0.9867 & 0.9870 & $1 \%$ \\
\hline - Yes & 0.0211 & 0.0133 & 0.0130 & $1 \%$ \\
\hline \multicolumn{5}{|l|}{ Index offence: other offences } \\
\hline - No & 0.8901 & 0.8724 & 0.9201 & $5 \%$ \\
\hline - Yes & 0.1099 & 0.1276 & 0.0799 & $5 \%$ \\
\hline \multicolumn{5}{|l|}{ Duration of forensic treatments to date (in weeks) } \\
\hline - $1-10$ & 0.2949 & 0.4254 & 0.3514 & $13 \%$ \\
\hline - $10-148$ & 0.3711 & 0.2192 & 0.3636 & $15 \%$ \\
\hline - $148-902$ & 0.3340 & 0.3554 & 0.2850 & $7 \%$ \\
\hline \multicolumn{5}{|l|}{ Severity of index offence } \\
\hline - 1 = homicide, attempted homicide & 0.2662 & 0.2997 & 0.3243 & $6 \%$ \\
\hline - 2 = sexual abuse of children, rape, sexual assault & 0.0768 & 0.0869 & 0.1036 & $3 \%$ \\
\hline - 3 = other sexual offence & 0.0403 & 0.0349 & 0.0259 & $1 \%$ \\
\hline - 4 = assault & 0.3094 & 0.2720 & 0.2850 & $4 \%$ \\
\hline - 5 = property crime & 0.1398 & 0.1002 & 0.0907 & $5 \%$ \\
\hline $\begin{array}{l}\text { - } 6=\text { threat, coercion, arson, criminal damage, traffic offence, offence } \\
\text { against controlled substances act, offence against weapons act, } \\
\text { misuse of emergency system, other offences }\end{array}$ & 0.1674 & 0.2063 & 0.1705 & $4 \%$ \\
\hline Estimated class population share & 0.3871 & 0.4043 & 0.2086 & \\
\hline Best match with Hodgins (2008) classification & $E S$ & $L S$ & $F O / L L S$ & \\
\hline Crime-schizophrenia-sequence variable & Class 1 & Class 2 & Class 3 & \\
\hline - ES & 0.4010 & 0.4458 & 0.1533 & \\
\hline - LS & 0.3800 & 0.3633 & 0.2568 & \\
\hline - LLS/FO & 0.3315 & 0.2725 & 0.3960 & \\
\hline
\end{tabular}

Note: A higher maximal inter-class difference in the posterior probabilities observed within the category of a given item indicates a more relevant finding. LLS = late late starter, FO = first offender, $L S=$ late starter, $E S=$ early starter.

have an impact, because it is estimated $20 \%$ of women will be diagnosed with schizophrenia after the age of 40 and generally four to six years later than men [35]. In conclusion, using age at first criminal registry entry (Fig. 2, A) may serve as a fair differentiator of offender patients into Hodgins' subgroups for future research when no more than one variable is available for subgrouping.

While helping to resolve prior inconsistencies, this study also has some limitations. These include the exclusion of those offenders with SSD waiting in Swiss prisons to be transferred to treatment in a forensic hospital, which generally is a problem in Switzerland [36]. This may indicate a selection bias.

Another methodological limitation pertains to the rather small difference between the BIC and scBIC values informing final model selection. Although this is a common issue, already encountered previously by the one other study to use a similar statistical approach [17], model-fit insecurity was addressed in this study by 
A Age at first criminal registry entry

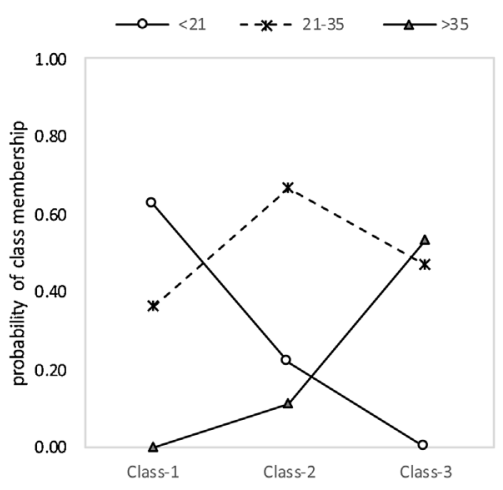

C

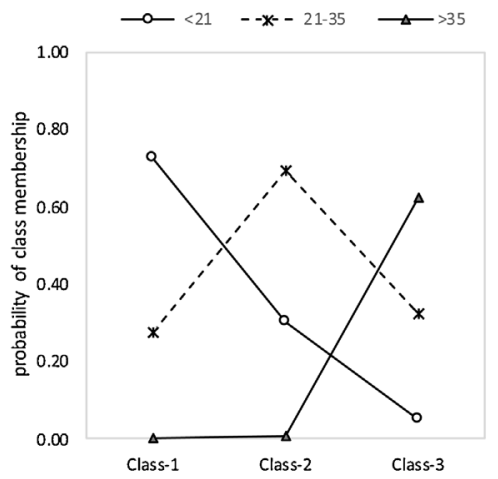

B Age at first diagnosis of SSD

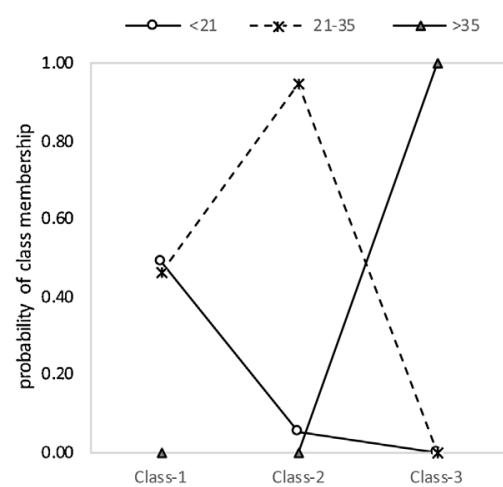

D Age at first inpatient treatment

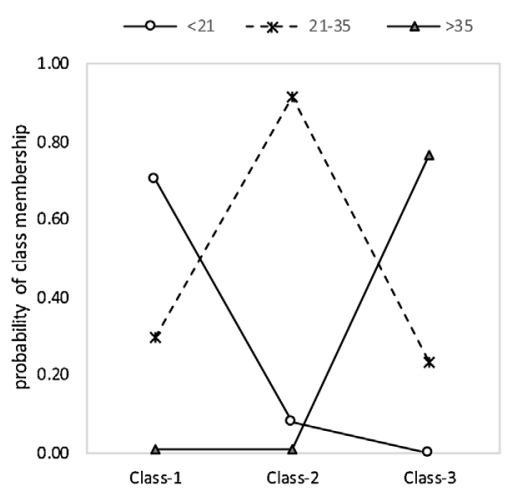

E Crime-schizophrenia-sequence variable

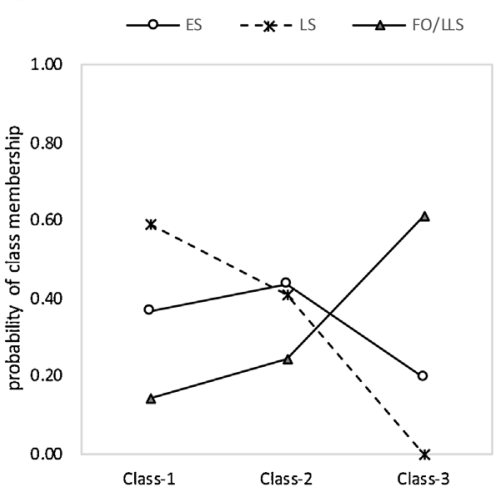

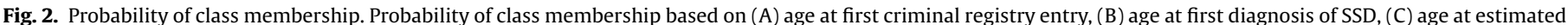

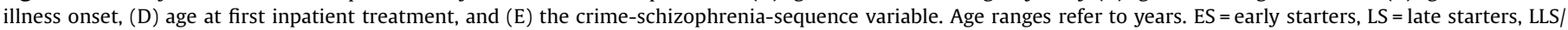
$\mathrm{FO}=$ late late starters/first offenders. Classes refer to the model-identified classes. Probabilities refer to the share of a given category within an individual class.

including a covariate defining the predicted typologies. This permitted a statistical comparison of the association with the identified model classes (Table 4). This analysis unfortunately is applicable only when a theoretically predicted classification variable is available. Therefore, the comparison could be performed only for the two- and three-class models. Nonetheless, given that the two- and three-class model fits did show the overall lowest BIC and scBIC values, it is reasonable to restrict statistical comparison to these two model fits. Despite very different sample characteristics (offenders with SMI instead of just SSD), a slightly different methodology (LPA instead of LCA, see introduction for critique on this choice), and separate analysis of male and female offenders, Penney et al. [17] observed similarly small differences between BIC values in their study. They did, however, use a different criterion for model selection (the Lo-Mendell-Rubin likelihood ratio test) favouring a two-class solution. This reflects limitations in the available statistical techniques for LCA model comparisons. At the same time, the number of subgroups of offenders with SSD may differ from that of offenders with SMI. Including a model-fit evaluation based on theoretically postulated patient typologies does enhance the validity of the three-class model identified in the current study.

Overall, it may be more important for prevention, early intervention, and treatment of offenders with SMI or SSD to provide further details on subgroups-including psychopathological variables and current treatment efficacy. Measuring the presence and extent of personality disorders and psychopathy [37] in addition to SSD could be a first step in that direction. This study considered personality disorders diagnosed prior to forensic admission, but available data was insufficient on the diagnosis of personality disorders after admission and (the relatively novel) psychopathy scores for a sufficient number of patients, which may be due to forensic hospitalizations considered in this study dating back as far as 1982. Future research should address this shortcoming by analysing psychopathology in more detail in more recent patient data.

\section{Funding}

This research did not receive any specific grant from funding agencies in the public, commercial, or not-for-profit sectors.

\section{Declarations of interest}

None.

\section{References}

[1] Fazel S, Gulati G, Linsell L, Geddes JR, Grann M. Schizophrenia and violence: systematic review and meta-analysis. PLoS Med 2009;6(8)e1000120.

[2] Wallace C, Mullen PE, Burgess P. Criminal offending in schizophrenia over a 25 year period marked by deinstitutionalization and increasing prevalence of comorbid substance use disorders. Am J Psychiatry 2004;161(4):716-27.

[3] Volavka J, Citrome L. Pathways to aggression in schizophrenia affect results of treatment. Schizophr Bull 2011;37(5):921-9.

[4] Hodgins S, Piatosa MJ, Schiffer B. Violence among people with schizophrenia: phenotypes and neurobiology. Neuroscience of aggression. Springer; 2013. p. 329-68.

[5] Tengström A, Hodgins S, Kullgren G. Men with schizophrenia who behave violently: the usefulness of an early-versus late-start offender typology. Schizophr Bull 2001;27(2):205-18.

[6] Hodgins S, Cree A, Alderton J, Mak T. From conduct disorder to severe mental illness: associations with aggressive behaviour, crime and victimization. Psychol Med 2008;38(7):975-87. 
[7] Jones RM, Van den Bree M, Ferriter M, Taylor PJ. Childhood risk factors for offending before first psychiatric admission for people with schizophrenia: a case-control study of high security hospital admissions. Behav Sci Law 2010:28(3):351-65.

[8] Kooyman I, Walsh E, Stevens H, Burns T, Tyrer P, Tattan T, et al. Criminal offending before and after the onset of psychosis: examination of an offender typology. Schizophr Res 2012;140(1-3):198-203.

[9] Laajasalo T, Hakkanen H. Offence and offender characteristics among two groups of Finnish homicide offenders with schizophrenia: comparison of early-and late-start offenders. J Forens Psychiatry Psychol 2005;16(1):41-59.

[10] Mathieu C, Côté G. A modelization of differences between early-and latestarter French-Canadian offenders. Int J Forensic Ment Health 2009;8 (1):25-32.

[11] Pedersen L, Rasmussen K, Elsass P, Hougaard H. The importance of early antisocial behaviour among men with a schizophrenia spectrum disorder in a specialist forensic psychiatry hospital unit in Denmark. Crim Behav Ment Health 2010;20(4):295-304.

[12] Sánchez-SanSegundo M, Ferrer-Cascales R, Herranz-Bellido J, Pastor-Bravo M, et al. Subtypes of severely mentally ill violent offenders in a Spanish forensic psychiatric hospital. Int J Forensic Ment Health 2014;13(3):217-26.

[13] Sirotich F. Putting criminal violence into context: a multi-level analysis of the correlates of violence severity among early-and late-start mentally disordered offenders: citeseer. 2009.

[14] Simpson AI, Grimbos T, Chan C, Penney SR. Developmental typologies of serious mental illness and violence: evidence from a forensic psychiatric setting. Aust N Z J Psychiatry 2015;49(11):1048-59.

[15] Van Dongen J, Buck N, Van Marle H. Unravelling offending in schizophrenia: Factors characterising subgroups of offenders. Crim Behav Ment Health 2015;25(2):88-98.

[16] Van Dongen JD, Buck NM, van Marle HJ. First offenders with psychosis: justification of a third type within the early/late start offender typology. Crime Deling 2014:60(1):126-42.

[17] Penney SR, Prosser A, Simpson AI. Age onset of offending and serious mental illness among forensic psychiatric patients: a latent profile analysis. Crim Behav Ment Health 2018.

[18] Hodgins S. Violent behaviour among people with schizophrenia: a framework for investigations of causes, and effective treatment, and prevention. Philos Trans Biol Sci 2008;363(1503):2505-18.

[19] Crocker AG, Martin MS, Leclair MC, Nicholls TL, Seto MC. Expanding the early and late starter model of criminal justice involvement for forensic mental health clients. Law Hum Behav 2018;42(1):83.
[20] Hsieh H-F, Shannon SE. Three approaches to qualitative content analysis. Qual Health Res 2005;15(9):1277-88.

[21] Brennan PF, Hays BJ. Focus on psychometrics the kappa statistic for establishing interrater reliability in the secondary analysis of qualitative clinical data. Res Nurs Health 1992;15(2):153-8.

[22] Lambert MJ, Bergin A. Handbook of psychotherapy and behavior change. John Wiley \& Sons; 1993.

[23] Habermeyer E, Wolff R, Gillner M, Strohm R, Kutscher S. Patienten mit schizophrenen Störungen im psychiatrischen Maßregelvollzug. Nervenarzt 2010;81(9):1117-24.

[24] Kutscher S, Schiffer B, Seifert D. Schizophrene Patienten im psychiatrischen Maßregelvollzug ( $\$ 63$ StGB) Nordrhein-Westfalens. Fortschritte der Neurologie. Psychiatrie. 2009;77(02):91-6.

[25] Seifert D. Die Entwicklung des psychiatrischen Massregelvollzzugs ( $\$$ 63StGB) in Nordrhein-Wesfalen. Psychiat Prax 1997;24:237-44.

[26] Greenland S, Finkle WD. A critical look at methods for handling missing covariates in epidemiologic regression analyses. Am J Epidemiol 1995;142 (12):1255-64.

[27] Zhou XH, Eckert GJ, Tierney WM. Multiple imputation in public health research. Stat Med 2001;20(9-10):1541-9.

[28] Van Buuren S, Boshuizen HC, Knook DL. Multiple imputation of missing blood pressure covariates in survival analysis. Stat Med 1999;18(6):681-94.

[29] Ambler G, Omar RZ, Royston P. A comparison of imputation techniques for handling missing predictor values in a risk model with a binary outcome. Stat Methods Med Res 2007;16(3):277-98.

[30] Asparouhov T, Muthén B. Variable-specific entropy contribution. Recuperado de http://wwwstatmodel com/download/UnivariateEntropy pdf. 2014.

[31] Soromenho G. Comparing approaches for testing the number of components in a finite mixture model. Comput Stat 1994;9(1):65-78.

[32] Roeder K, Wasserman L. Practical Bayesian density estimation using mixtures of normals. J Am Stat Assoc 1997;92(439):894-902.

[33] Linzer DA, Lewis JB. poLCA: An R package for polytomous variable latent class analysis. J Stat Softw 2011;42(10):1-29.

[34] Seeman MV. Women and psychosis. Women's Health 2012;8(2):215-24.

[35] Riecher-Rössler A. Early detection of schizophrenic psychoses in men and women. Ther Umsch 2007;64(6):337-43.

[36] Steinau S, Brackmann N, Sternemann U, Biller-Andorno N, Habermeyer E. Conflicting priorities between risk management and mental health treatment-a case report. Front Psychiatry 2018;9:680.

[37] Hare RD, Neumann CS. Psychopathy as a clinical and empirical construct. Annu Rev Clin Psychol 2008;4:217-46. 